\title{
Dioxin-induced changes in epididymal sperm count and spermatogenesis
}

\author{
Mudanças induzidas por dioxina \\ na contagem epididimal de esperma e espermatogênese
}

Warren G. Foster ${ }^{1}$

Serena Maharaj-Briceño ${ }^{1}$

Daniel G. Cyr ${ }^{2}$
This article was originally published by Environ Health Perspect 118:458-464 (2010).doi:10.1289/ ehp.0901084 [Online 17 December 2009] and is part of the scientific collaboration between Cien Saude Colet and EHP.

${ }^{1}$ Reproductive Biology Division, HSC-3N52D, Department of Obstetrics and Gynecology, McMaster University, 1200 Main St W, Hamilton, ON, Canada, L8N 3Z5.fosterw@mcmaster.ca ${ }^{2}$ INRS-Institut ArmandFrappier, Université du Québec, Laval, Quebec, Canada.
Abstract A single in utero exposure to 2,3,7,8tetrachlorodibenzo-p-dioxin (TCDD) on gestation day 15 decreased epididymal sperm count in adult rats and thus was used to establish a tolerable daily intake for TCDD. However, several laboratories have been unable to replicate these findings. Moreover, conflicting reports of TCDD effects on daily sperm production suggest that spermatogenesis may not be as sensitive to the adverse effects of TCDD as previously thought. We performed a PubMed search using relevant search terms linking dioxin exposure with adverse effects on reproduction and spermatogenesis. Developmental exposure to TCDD is consistently linked with decreased cauda epididymal sperm counts in animal studies, although at higher dose levels than those used in some earlier studies. However, the evidence linking in utero TCDD exposure and spermatogenesis is not convincing. Animal studies provide clear evidence of an adverse effect of in utero TCDD exposure on epididymal sperm count but do not support the conclusion that spermatogenesis is adversely affected. The mechanisms underlying decreased epididymal sperm count are unknown; however, we postulate that epididymal function is the key target for the adverse effects of TCDD.

Key words Development, Dioxin, Endocrine, Reproduction, Spermatogenesis
Resumo Uma única exposição in utero a 2,3,7,8tetrachlorodibenzo-p-dioxin (TCDD) no $15^{\circ} \mathrm{dia}$ de gestação diminuiu a contagem de esperma epididimal em ratos adultos e por isso foi utilizada para estabelecer uma dosagem diária tolerável para TCDD. No entanto, diversos laboratórios não conseguiram reproduzir esses resultados. Além disso, relatórios conflitantes dos efeitos de TCDD na produção diária de esperma sugere que espermatogênese pode não ser tão sensível aos efeitos adversos do TCDD como antes se pensava. Foi feita uma pesquisa no PubMed usando termos de pesquisa relevantes, relacionados à exposição à dioxina com efeitos adversos na reprodução e na espermatogênese. Exposição em desenvolvimento ao TCDD é consistentemente relacionada à diminuição da contagem da cauda epididimal de esperma, mas não apoia a conclusão de que a espermatogênese é afetada. Os mecanismos por trás da diminuição da contagem de esperma epididimal são desconhecidos; no entanto, contestamos que a função epididimal é a chave para efeitos adversos do TCDD.

Palavras-chave Desenvolvimento, Dioxina, Endócrino, Reprodução, Espermatogênese 
Dioxins are lipophilic chemicals that resist biological and environmental degradation, making them persistent in the environment. Seventy-five dioxin congeners and 135 furan congeners comprise the complex mixture of dioxins, of which 7 and 10 congeners, respectively, are capable of binding to and activating the aryl hydrocarbon receptor (AhR) (Van den Berg et al. 2006). Of the 209 polychlorinated biphenyl (PCB) congeners, 12 have the potential to activate the AhR (Van den Berg et al. 2006). Among these, 2,3,7,8-tetrachlorodibenzo-p-dioxin (TCDD) is the most toxic environmental contaminant in animal studies (Denison and Nagy 2003) and thus is significant for human health (Birnbaum 1994; Larsen 2006; Schecter et al. 2006).

Dioxins are by-products of industrial processes such as chlorine bleaching of pulp and paper, the manufacture of certain pesticides, and incineration of medical waste and plastics (Anderson and Fisher 2002; Hewitt et al. 2006; Lin et al. 2006; Thornton et al. 1996). Resistance to degradation leads to bioaccumulation and biomagnification of dioxins in the food chain. Inclusion of animal fat in animal feed is another route of dioxin entry to the food supply and a source of exposure (Hoogenboom et al. 2007). Human exposure is primarily through consumption of contaminated food, especially high-fat foods such as milk, cheese, meat, some fish, fast foods, and breast milk (Schecter and Li 1997; Schecter et al. 1997, 1998a, 1998b, 2001). Residue levels have been measured in the serum of pregnant Canadian women with a mean $\pm \mathrm{SE}$ of $0.34 \pm 0.01 \mathrm{pg} \mathrm{TCDD} / \mathrm{g}$ lipid (Foster et al. 2005), lower than the serum concentrations measured in pregnant German women (range, 4.34$97.3 \mathrm{pg}$ TCDD/g lipid; Wittsiepe et al. 2007) and women from central Taiwan (mean, 6.7pg TCDD/ g lipid; Wang et al. 2004). The different concentrations in these studies reflect differences in measurement techniques; a gene reporter assay [chemical-activated luciferase gene expression (CALUX) assay] and high-resolution mass spectrometry have been used to quantify World Health Organization (WHO) toxic equivalence quotient concentrations or dioxin-like activity. Regardless, these studies demonstrate that the fetus is exposed to dioxin-like chemicals during a critical window of development. The half-life of dioxin ranges from 5.8 to 14.1 years in humans and is influenced by body composition, with higher body fat associated with a longer half-life (Michalek et al. 1992, 1996, 2002). By comparison, the half-life ranges from 10 to 15 days in mice (Grassman et al. 1998) and is approximately 3 weeks in rats (Rose et al.
1976). Given the documented adverse effects on the adult rat reproductive tract after a single in utero exposure to TCDD, developmental exposure and differences in the half-life of TCDD could have important consequences for the relevance of results from animal studies for human health.

Experimental evidence demonstrates that most toxic actions of TCDD are mediated through the AhR, which is a ligand-activated transcription factor (Robles et al. 2000) ubiquitously expressed in many human tissues and cell lines (Dolwick et al. 1993; Harper et al. 1991; Li et al. 1998). AhR is inactive and unbound in the cytoplasm. Upon ligand binding, the AhR binds to the aryl hydrocarbon nuclear translocator (ARNT) protein, resulting in translocation to the nucleus, where the ligand-AhR-ARNT complex binds to response elements in the promoter of AhR-regulated genes (dioxin response element).

In humans, exposure to dioxins has been linked to a variety of adverse effects, includ-ing chloracne (Baccarelli et al. 2005a, 2005b), immune suppression (Weisglas-Kuperus et al. 2000), thyroid dysfunction (Koopman-Esseboom et al. 1994; Pavuk et al. 2003), increased risk for diabetes (Longnecker and Michalek 2000) and endometriosis (Eskenazi et al. 2000; Heilier et al. 2007), impaired neurodevelopment (KoopmanEsseboom et al. 1996; Vreugdenhil et al. 2002), and reproductive/developmental abnormalities (Dimich-Ward et al. 1996; Halldorsson et al. 2009; Leijs et al. 2008; Mocarelli et al. 1996, 2000, 2008). A number of studies attribute background dioxin exposure to adverse effects on development or pathophysiology in multiple organ systems. However, the results of these studies are controversial, and it is not possible to establish causal associations; thus, animal studies are essential.

In animal studies, dioxin exposure has been shown to cause thymic atrophy (Chahoud et al. 1989), immune suppression (Hogaboam et al. 2008), hepatotoxicity (Chahoud et al. 1989), and impaired thyroid function (Fan and Rozman 1995; Henry and Gasiewicz 1987; Kohn 2000). Of these, TCDD effects on the reproductive tract are the most notable, owing to the sensitivity of this system. Developmental exposure to TCDD induces placental dysfunction (Ishimura et al. 2006; Kawakami et al. 2006); decreased offspring survival (Bell et al. 2007a, 2007b; Bjerke and Peterson 1994; Flaws et al. 1997; Gray and Ostby 1995; Gray et al. 1995, 1997b; Roman et al. 1995; Sommer et al. 1996); developmental defects of the palate, heart, and kidney (Aragon et al. 2008; Birn- 
baum et al. 1989; Theobald and Peterson 1997) and reproductive tract of males (Gray et al. 1997a; Vezina et al. 2008) and females (Flaws et al. 1997; Gray and Ostby 1995; Gray et al. 1997b; Heimler et al. 1998; Wolf et al. 1999); decreased weights of reproductive organs (Bjerke and Peterson 1994; Gray and Ostby 1995; Gray et al. 1995, 1997a; Loeffler and Peterson 1999; Mably et al. 1992a, 1992c; Moore et al. 1985; Ohsako et al. 2001, 2002; Wolf et al. 1999); delayed onset of sexual maturation (Bjerke et al. 1994; Faqi and Chahoud 1998; Flaws et al. 1997; Gray et al. 1997a, 1997b); feminization of males (Bjerke et al. 1994; Mably et al. 1992b); and decreased sperm counts (Faqi et al. 1998; Gray et al. 1995, 1997a; Mably et al. 1992a; Sommer et al. 1996). Of the reproductive/developmental effects of TCDD, decreased sperm counts are considered as the most sensitive outcome. Mably et al. (1992a) reported that epididymal sperm counts were significantly decreased in rats after a single exposure to $0.064 \mu \mathrm{g}$ TCDD/ $\mathrm{kg}$ on gestational day (GD) 15 . Similarities in spermatogenesis between rats and humans, together with the marked apparent sensitivity of sperm production to the adverse effects of TCDD exposure, has yielded the establishment of a tolerable daily intake of approximately $2 \mathrm{pg} / \mathrm{kg} /$ day for TCDD and related compounds by the WHO [Joint FAO/ WHO (Food and Agriculture Organization/WHO) Expert Committee on Food Additives 2001]. However, results of recent studies have been unable to reproduce the effect of in utero TCDD exposure on epididymal sperm counts (Bell et al. 2007a, 2007c; Ohsako et al. 2001; Yonemoto et al. 2005), although one study did report a decrease in epididymal sperm counts with a TCDD concentration of $1 \mu \mathrm{g} / \mathrm{kg}$ (Ohsako et al. 2001). Reasons for the divergent results are unclear, but differences in methodology used to quantify sperm count could account for the observed differences. In addition, disparities in dioxin toxicokinetics and species sensitivity to dioxins raise important questions concerning the use of animal models to estimate human risk (Adler 1996; Aylward et al. 2005; Simanainen et al. 2004a, 2004b). Therefore, the objective of this review is to evaluate the effects of TCDD exposure on spermatogenesis.

We undertook a systematic review of the literature and performed a PubMed (National Center for Biotechnology Information 2009) search using the following search terms: dioxin, TCDD, reproductive, developmental, testis, spermatogenesis, sperm, semen quality, fertility, and fecundity. The search yielded 4,224 titles; duplicate pa- pers, review articles, letters to the editor, and articles describing tissue culture or nonmammalian studies were excluded from further analysis. The abstracts of all remaining articles were read by two independent investigators and were included for further analysis if they fit the following criteria: $a$ ) the paper was published in English, $b$ ) the abstract described an epidemiologic or animal study in which TCDD or dioxin-like chemicals were either measured in human tissues or administered to experimental animals; and $c$ ) effects on reproductive organs, sperm count, and sperm characteristics were assessed. From the original data set, 33 articles described the reproductive toxicity of TCDD; of these, 9 specifically examined the effect of a single in utero TCDD exposure on spermatogenesis. For each paper, we extracted details of the experimental methods and the resulting data for further study.

\section{Dioxin exposure and spermatogenesis}

Of the reproductive/developmental effects documented in the literature, spermatogenesis is considered the most sensitive adverse effect of TCDD exposure, as shown by the use of this end point by the WHO in setting its tolerable daily intake for TCDD (Joint FAO/WHO Expert Committee on Food Additives 2001). Sperm counts are decreased by up to $36 \%$ compared with con-trols (Bjerke and Peterson 1994), with the lowest effective dose of $0.064 \mu \mathrm{g}$ TCDD/kg body weight (BW) reported for Holtzman rats (Mably et al. 1992a). GD15 is the most sensitive time point for the adverse effects of TCDD exposure because effects on spermatogenesis in rats with lactational exposure were less pronounced (Bjerke and Peterson 1994). Furthermore, the effects are thought to be AhR mediated because severity of the TCDD effect on epididymal sperm count is modified in rats bearing different resistance alleles (Simanainen et al. 2004a, 2004b).

Although the process of spermatogenesis is qualitatively similar in rats and humans, there are important differences. In rats, spermatogenetic cycles begin every 12.9 days, whereas in humans there are 16days between cycles; a spermatogenic cycle requires 52-54 days in rats and 65 days in humans to complete (Adler 1996; Hess et al. 1990; Robb et al. 1978). Spermatogonial differentiation lasts 12 days in rats and 16 days in humans (Adler 1996), and development of spermatocytes requires 14 days in rats and 25 days in humans. Spermiogenesis, the process of differ- 
entiation of haploid germ cells from round to elongated spermatids, takes another 7-14days in rats and $8-17$ days in humans. Throughout spermatogenesis, genes are differentially expressed in a stage-dependent manner (Pang et al. 2006), and transcripts for $A h R$ and ARNT have been documented in the rat testes, epididymides, seminal vesicles, vas deferens, and prostate (Roman et al. 1998). In humans, the $A h R$ and ARNT are expressed in spermatocytes, where they are thought to play a role in regulating apoptosis of spermatocytes (Schultz et al. 2003). Therefore, all of the requisite signaling machinery is present in the testis of both rats and humans. There is limited evidence that developmental exposure to TCDD results in testicular exposure. The highest maternal dose of TCDD used $(0.8 \mu \mathrm{g}$ TCDD $/ \mathrm{kg} \mathrm{BW})$ in one study resulted in testicular levels of $0.49 \mathrm{pg}$ $\mathrm{TCDD} / \mathrm{g}$ wet testis on postnatal day (PND) 120 , demonstrating that residue levels in target tissue can persist throughout the animal's life (Ohsako et al. 2001). However, the relevance of animal studies to human risk is still questionable. First, although human exposure to dioxin and dioxinlike chemicals continues to be widespread, tissue residue levels are low relative to the concentrations used in animal studies. Second, the timing of TCDD exposure appears to be critical in establishing the previously documented adverse reproductive phenotype (Mably et al. 1992a). Welsh et al. (2008) suggested a window of programming for the male reproductive tract during embryonic development and described the presence of early (GD15.5-GD17.5), middle (GD17.5-GD19.5), and late (GD19.5-GD21) windows of development, which correspond to the period of development after the onset of fetal androgen production by the rat testis (GD15.5GD17.5). Subsequent masculinization of the reproductive tract occurs with the morphologic differentiation of the epididymis, vas deferens, seminal vesicles, and prostate, as well as external genitalia (penis, scrotum, and perineum). Fetal androgen development in humans occurs during weeks 8-37 of gestation (Siiteri and Wilson 1974 ), so the early programming window of development in rats corresponds to weeks 8-14 of development in humans (Welsh et al. 2008). Assuming similar effects in humans, exposure to chemical toxicants, including dioxin, would have to occur during the first trimester of human fetal development to produce a phenotype similar to that observed in rats (Sharpe 2009). However, in humans, the greatest exposure to dioxins occurs during lactation, a period during which rodents are relatively insensitive to the adverse effects of TCDD treatment (Bjerke and Peterson 1994).

The effect of developmental exposure to TCDD on spermatogenesis in rats has raised concerns for potential effects in humans. However, several studies in rats (Bell et al. 2007a; Ohsako et al. 2001; Yonemoto et al. 2005) using similar experimental designs have been unable to replicate the reduction in sperm number reported by Mably et al. (1992a), raising questions concerning the validity of the conclusions and their relevance to human health. Although the reasons are unclear, differences in rat strains cannot account for the divergent results because conflicting results have been documented in all rat strains used to date. It is noteworthy that although several studies have been unable to replicate the findings of Mably et al. (1992a), decreased epididymal sperm counts have been demonstrated at a concentration of $1.0 \mu \mathrm{g} / \mathrm{kg}$ (Ohsako et al. 2001). Others speculate that statistically robust studies employing large sample sizes (25-60 litters/treatment group) are more appropriate and likely to yield more reliable results (Bell et al. 2007a, 2007b). However, effects of TCDD on spermatogenesis have been reported in studies with as few as 35 litters (Wilker et al. 1996) to as many as 9-12litters (Bjerke and Peterson 1994; Gray et al. 1997b; Sommer et al. 1996) per treatment group. Although sample sizes in these studies are small, our calculations demonstrate that to detect a difference of $15 \times 10^{6}$ sperm $/ \mathrm{mL}$ with an SD of approximately $8.5 \times 10^{6}$, a power of 0.80 , and an alpha of 0.5 , a sample size of 9 animals/treatment group would be sufficient. Hence, we conclude that most of the reviewed studies were adequately powered and that the documented effects are not likely due to statistical artifact. Rather, we suggest that the divergent results may be due to differences in methods employed to quantify sperm, which have been surprisingly different and range from automated methods to manual counts with a hemocytometer. Indeed, some sperm-counting methodologies can be highly variable, with coefficients of variation as high as $40 \%$ as seen in the studies by Bell et al. (2007a, 2007b). Hence, although studies need to be adequately powered, it is also imperative that sensitive outcome measures be employed.

In quantifying sperm count in reproduc-tive/ developmental toxicity studies, we propose that there is a need to standardize the methods used, and we favor manual counts with a hemocytometer over automated methods. Furthermore, we found different methods of reporting sperm 
counts [daily sperm production (DSP)/whole testis (Wilker et al. 1996), DSP/g testis (Wilker et al. 1996), testicular spermatid head count (Gray et al. 1995), and sperm counts from whole epididymis (Bell et al. 2007a, 2007b), caput/corpus epididymis (Gray et al. 1997b; Sommer et al. 1996; Wilker et al. 1996), cauda epididymal sperm (Bjerke and Peterson 1994; Gray et al. 1995; Mably et al. 1992a; Ohsako et al. 2001, 2002; Sommer et al. 1996; Wilker et al. 1996; Yonemoto et al. 2005), and ejaculated sperm (Gray et al. 1995; Sommer et al. 1996)] thus making comparisons difficult. Only two studies (Sommer et al. 1996; Wilker et al. 1996) measured DSP, caput/corpus sperm, and caudal epididymal sperm counts, permitting assessment of potential target sites of TCDD. Interestingly, although both studies agree on the effect of TCDD on caudal epididymal sperm counts, they diverge on the measure of DSP. Furthermore, different time points have been employed to quantify sperm, ranging from PND49, representing puberty (Ohsako et al. 2001; Yonemoto et al. 2005), to 15 months of age (Gray et al. 1995), with most studies quantifying sperm counts between PND63 and PND120, corresponding to postpubertal and adult stages, respectively. Because male rodents are not sexually mature before approximately PND 50 and because a spermatogenic cycle takes 52-54days to complete in the rat (Adler 1996; Robb et al. 1978), measurement of sperm counts in rats before PND70 is likely to produce ambiguous results. Nonetheless, six of eight studies reported a TCDD-induced decrease in cauda epididymal sperm counts (Bjerke and Peterson 1994; Gray et al. 1997b; Mably et al. 1992a; Ohsako et al. 2002; Sommer et al. 1996; Wilker et al. 1996), whereas the evidence for changes in DSP are more variable, with only three of six studies finding a significant decrease (Bjerke and Peterson 1994; Mably et al. 1992a; Sommer et al. 1996). The variable results for DSP are more difficult to interpret because sperm production can be affected by many factors, including nutrition, infection, and general health of the animal, as well as time from last ejaculation and toxicant effects on the hypothalamic-pituitary-testicular axis.

Prior studies have demonstrated treatmentrelated decreases in BW (Bjerke and Peterson 1994; Sommer et al. 1996) and absolute testicular weight (Bjerke and Peterson 1994; Mably et al. 1992a; Sommer et al. 1996), suggesting a potential effect of TCDD; however, relative testicular weights, when reported, were unchanged (Bjerke and Peterson 1994; Ohsako et al. 2002; Sommer et al. 1996), indicating that the testes were unaffected. Circu- lating levels of follicle-stimulating hormone (FSH), luteinizing hormone, and testosterone were unchanged (Bjerke and Peterson 1994; Mably et al. 1992a; Ohsako et al. 2001), suggesting that the hypothalamic-pituitary-testicular axis was also unaffected by TCDD. Morphologic assessment of the testes also failed to demon-strate evidence of treatment-related effects. In one study, testicular atrophy and separation of the caput and caudal regions with a loss of corpus epididymis was observed in two rats, which were excluded from the analysis (Ohsako et al. 2001).

Other than abstinence, Sertoli cell number is a central determinant of sperm count (Sharpe et al. 2003). In humans, Sertoli cell proliferation takes place during fetal, postnatal (0-8 months of age), and prepubertal development. Animal studies in mice and rats reveal that androgens primarily regulate Sertoli cell proliferation during the perinatal and prepubertal periods (Atanassova et al. 2005; De Gendt et al. 2004; Tan et al. 2005a, 2005b), whereas FSH plays a more central role in the peripubertal period (Johnston et al. 2004). Direct effects of developmental exposure to TCDD on the spermatocyte to Sertoli cell ratios were measured in adult Holtzman rats exposed to TCDD on GD15 (Mably et al. 1992a). TCDD did not affect the spermatocyte to Sertoli cell ratio at any age (PNDs 49, 63, or 120), leading to speculation of a defect in germ cell division or an increase in apoptosis of germ cells. Morphologic changes to the testis have been demonstrated in adult rats exposed to a single injection of either 3.0 or $5.0 \mu \mathrm{g}$ TCDD/kg BW, whereas doses of 0.5 and $1.0 \mu \mathrm{g}$ TCDD/kg BW had no effect on the testis (Chahoud et al. 1992). In that study, the number of spermatids per testis was decreased by TCDD treatment, and the spaces between adjacent Sertoli cells were enlarged, indicating dissolution of the germinal epithelium. Similarly, contacts between Sertoli cells and spermatogonia were disrupted in a subchronic study in rats treated with an initial dose of 25 or $75 \mu \mathrm{g}$ TCDD/kg BW followed by a once-weekly maintenance dose of either 5 or $15 \mu \mathrm{g} / \mathrm{kg}$, respectively, for 10 weeks (Chahoud et al. 1989). However, Sertoli cell changes were only seen at high doses, which are well beyond the concentrations reported to induce changes in DSP and epididymal sperm counts (Mably et al. 1992a). Thus, it is unlikely that TCDD-induced changes in sperm counts can be attributed to changes in Sertoli cell structure or function. Therefore, we propose that the primary effect of TCDD is not on the testes or on spermatogenesis. We postulate that adverse ef- 
fects of TCDD are more likely related to developmental abnormalities of the reproductive tract and epididymal structure and/or function.

\section{Alternative modes of dioxin action}

TCDD-induced changes in cauda epididymal sperm counts and decreased weights of androgen target tissues such as the seminal vesicle, epididymides, and prostate provide clear evidence of developmental toxicity. The mechanism(s) of action underlying these responses remains unclear. Modes and/or mechanisms of action of dioxin-induced changes in cauda epididymal sperm counts and reproductive tract structure and function of potential relevance to human health include dysregulation of androgen signaling and enhanced phagocytosis of germ cells (reviewed by Phillips and Tanphaichitr 2008) and enhanced epididymal sperm transit.

\section{Dysregulation of androgen signaling}

Circulating levels of testosterone and dihydrotestosterone (DHT) were decreased in adult rats exposed to high concentrations of TCDD in both time-course $(15 \mu \mathrm{g}$ TCDD $/ \mathrm{kg} \mathrm{BW})$ and dose-response $(100 \mu \mathrm{g}$ TCDD/kg BW) studies (Moore et al. 1985). Similarly, serum testosterone concentrations were significantly reduced in adult male rats treated with $25.0 \mu \mathrm{g} \mathrm{TCDD} / \mathrm{kg}$ BW and sacrificed 4 weeks later (Johnson et al. 1992). However, the concentration of TCDD needed to induce a change in circulating testosterone levels is very high relative to the doses that alter sperm counts and those docuented in human exposure. Decreased seminal vesicle and epididymal weights corroborated the reduced circulating testosterone levels; however, DSP or testis weights were unaffected, suggesting that TCDD may have affected Leydig cell function, and morphologic assessment of the testes revealed a decrease in Leydig cell volume. In three different rat strains bred from TCDD-resistant and -sensitive strains, circulating levels of testosterone were decreased 17 days after treatment with a single oral dose of $1,000 \mu \mathrm{g}$ TCDD $/ \mathrm{kg} \mathrm{BW}$ (Simanainen et al. 2004a). Similarly, in utero exposure to the highest dose of TCDD (an initial dose of $300 \mathrm{ng}$ TCDD/kg BW followed by a maintenance dose of $60 \mathrm{ng} \mathrm{TCDD} / \mathrm{kg}$ BW for the 2 weeks before mating) induced a $50 \%$ decrease in plasma testosterone levels (Faqi et al. 1998). Mably et al. (1992c) found a 60\% decrease in plas- ma testosterone and a $41 \%$ reduction in DHT after in utero exposure to a single dose of TCDD, which although substantial, was not significant, whereas other investigators were unable to find treatment-induced changes in circulating androgen levels (Gray et al. 1995; Loeffler and Peterson 1999; Roman et al. 1995). In contrast, $1 \mu \mathrm{g}$ TCDD/ $\mathrm{kg}$ BW administered on GD15 increased circulating levels of testosterone on PND70 in three different rat strains with different sensitivities to TCDD (Simanainen et al. 2004b). No differences in circulating levels of FSH or testosterone were documented in adult Holtzman rats exposed to TCDD on GD15 (Mably et al. 1992a). Therefore, the reduction in sperm counts reported in animal studies is unlikely the consequence of TCDDinduced changes in serum androgen levels ( $\mathrm{Si}$ manainen et al. 2004a, 2004b) or effects on Leydig cell structure or function.

Dysregulation of testosterone signaling has been documented in several animal studies but not detected in others. TCDD treatment induced a decrease in androgen receptor (AR) gene expression in ventral prostate and decreased weight, both evidence of decreased androgen signaling (Ohsako et al. 2001). Morrow et al. (2004) reported that activation of the AhR in LnCAP prostate cells by TCDD could inhibit androgen-dependent proliferation, which was mediated by crosstalk between the AhR and the AR. Transcriptional regulation of AR signaling (Kollara and Brown 2006) by competition between the AR and the AhR for nuclear transcription factors is another possibility (Kollara and Brown 2006). Competition between the AhR and AR for transcription factors has been documented in breast cancer cell lines (Kollara and Brown 2006); however, although intriguing, its relevance to the testis and human cells in vivo and during development of the male reproductive tract remains unknown.

\section{Dysregulation of epididymal function}

Reports that a single TCDD injection on GD15 results in decreased epididymal or cauda epididymal sperm counts without effect on testicular DSP are difficult to reconcile. We postulate that the adverse effects of TCDD are mediated via changes in epididymal function as opposed to effects on the testes. Changes in sperm transit through the excurrent duct system or increased removal of damaged sperm from the epididymis could provide reasonable alternative explanations to TCDD effects on spermatogenesis. Several laboratories have examined TCDD treatment on 
sperm transport through the epididymides with divergent results. High-dose in utero and lactational exposure to TCDD (an initial dose of 25$300 \mathrm{ng}$ TCDD/kg followed by 5-60ng TCDD/kg throughout premating, mating, pregnancy, and lactation) decreased the time for sperm to transit through the epididymides in Wistar rats (Faqi et al. 1998). In contrast, exposure to $1.0 \mu \mathrm{g}$ TCDD/ $\mathrm{kg}$ on GD15 had no effect on sperm transit in Holtzman rats, suggesting that phagocytosis of sperm in the epididymides is increased (Sommer et al. 1996). Exposure of C57BL/6 mice to TCDD (0.1-50 $\mu \mathrm{g}$ TCDD $/ \mathrm{kg}$ ) for $24 \mathrm{hr}$ resulted in a decrease in spermatozoan mitochondrial membrane potential compared with vehicle-treated control mice (Fisher et al. 2005). The effect was not evident in AhR-knockout mice, demonstrating that the effect requires activation of the AhR. However, there was no increase in the number of apoptotic germ cells in the testis and no change in morphology of the testis and epididymis.

In general, phagocytosis of spermatozoa by the epithelial cells of the cauda epididymidis is very low. It has previously been suggested that damaged spermatozoal cells can be phagocytosed (Sutovsky et al. 2001), but the interpretation of these data has been challenged (Cooper et al. 2002). Furthermore, if TCDD treatment did stimulate phagocytosis to the extent that sperm counts decreased by almost $40 \%$, one would expect this to be obvious when examining the morphology of the epididymis. This does not appear to be the case, given the lack of reference of such an effect. A second possibility is that the blood-epididymal barrier is compromised, resulting in activation of the immune system, thus allowing macrophages to readily enter the lumen of the epididymis and attack maturing spermatozoa (Cyr et al. 2007). Although this may explain the loss of epididymal spermatozoa, we found no reports of large numbers of macrophages within the epididymal lumen. A more likely possibility is that spermatozoa transit time is altered, resulting in fewer spermatozoa stored in the cauda epididymis. The epididymis is a long, open-ended, and highly convoluted tubule (Robaire et al. 2006). Spermatozoa are stored in the cauda epididymidis, but the retention of spermatozoa in this region is not well understood. Perhaps the best explanation is related to the length and high degree of convolution in this region of the epididymis. Changes in the convoluted nature of the cauda or the length of the cauda could directly affect the quantity of spermatozoa retained in the epididymis. Antiandrogenic compounds such as phtha- lates reportedly alter epididymal development and coiling of the epididymal tubule (Barlow and Foster 2003), and flutamide significantly reduces the size of the cauda epididymis (McKinnell et al. 2000); however, whether the length of the epididymal tubule is also reduced is unknown. Wilker et al. (1996) reported that neonatal administration of TCDD resulted in a loss of epididymal segmentation, although they did not report whether this is associated with alterations in the cauda. Epididymal sperm transit time may also be affected by changes in the composition of epididymal fluid. Water is reabsorbed from the seminal fluid in the efferent ducts between the testis and epididymis (Hess 2002), a process regulated by estradiol and mediated by estrogen receptor$\alpha(\mathrm{ER} \alpha)$ (Zhou et al. 2001). TCDD is known to block estrogen action by activating the AhR, which has been shown to partly bind to the estro-gen response element of estrogen-dependent genes (Safe et al. 1998). In the epididymis, after treatment with antiestrogens, or in ER $\alpha$-knockout mice, there is retention of water in the seminal fluid (Zhou et al. 2001), which is associated with a decrease in cauda epididymal sperm counts (Ruz et al. 2006). Less concentrated sperm would exhibit faster transit time, particularly in the cauda epididymis, because fluid pressure in the epididymal lumen would likely be increased. Thus, the effect of dioxin and dioxin-like chemicals on epididymal structure and function requires further study.

\section{Epidemiology}

Semen quality and sperm counts have report-edly declined approximately $2 \%$ per year for about 50 years (Carlsen et al. 1992). That provocative review (Carlsen et al. 1992) led to an explosion of studies, some of which reported a decline in semen quality (Auger et al. 1995; Irvine et al. 1996; Younglai et al. 1998) and some of which did not (Pal et al. 2006). Although the reported decline in sperm counts remains controversial, there appears to be consensus for regional differences in semen quality (Jorgensen et al. 2001, 2002, 2006). Geographic differences in semen quality may also be accounted for by differences in race, genetic background, lifestyle, diet, and exposure to environmental toxicants.

Environmental contaminants have received growing attention, in part because animal studies have shown that some chemicals reduce sperm counts and because human exposure to environ- 
mental pollutants is potentially modifiable. Reduced sperm counts have been documented in studies of men occupationally exposed to different environmental contaminants (De Celis et al. 2000; Eskenazi et al. 1991), but the relationship between dioxin exposure and semen quality remains ambiguous. No difference in semen quality was found in Taiwanese men exposed prenatally to rice oil contaminated with PCBs and polychlorinated dibenzofurans (Yu-Cheng accidental exposure), despite the occurrence of chloracneclear evidence of AhR activation (Guo et al. 2000). However, sperm con-centration and sperm motility were decreased in dioxin-exposed young healthy men from Belgium, a region with high dioxin contamination (Van Waeleghem et al. 1996), and total sperm count was decreased in Belgian men from Flanders (Comhaire et al. 2007). In 101Flemish men 5 months after expo-sure to PCB- and dioxin-contaminated food, Dhooge et al. (2006) observed that semen vol-ume was decreased but sperm concentration was increased with an increase in dioxin-like activity (CALUX assay). The increased sperm concentration can be explained by decreased semen volume in these men, whereas total and free testosterone levels were also decreased with increasing dioxin-like activity. In contrast, no relationship between dioxin-like activity and semen parameters was found in Inuit men and men from three European populations with tissue residue levels representative of background exposure (Toft et al. 2007).

It is difficult to compare studies because of differences in reporting results, such as sperm count versus sperm concentration, methods of quantifying dioxin exposure, and differences in controlling for confounding factors such as age, smoking history, influence of mothers smoking during pregnancy, time from last ejaculation, use of medications known to affect semen quality, and health status of the study subjects. Another factor that may be important is the subject's age at time of exposure, as shown in a recent study of semen quality in men acutely exposed to high levels of TCDD in Seveso, Italy (Mocarelli et al. 2008). In that study, men were stratified on the basis of their age at the time of exposure; men who were adults at the time of exposure showed no effects, while sperm counts were increased in men exposed during the peripubertal period. However, decreased sperm concentrations were observed in men who were between 1 and 9 years of age at the time of exposure (mean age, 6.2 years). Mocarelli et al. (2008) also reported a decreased percentage of motile sperm and of progressively motile sperm, without any effect on circulating testosterone levels, suggesting a critical time window for dioxin exposure during which the developing reproductive tract is more sensitive; this is consistent with the animal literature. In contrast to the animal literature, these human exposures were associated with a decrease in semen characteristics, especially motility. Taken together, epidemiologic data suggest that dioxin exposure affects the function of sex glands with a decreased semen volume but with no change in sperm count; these data are, in part, consistent with the animal literature but contradictory to a definitive effect of dioxin on spermatogenesis. Moreover, although preliminary, the epidemiologic data also suggest that concentration and developmental stage at the time of exposure may be an important determinant of dioxin effects on semen quality in the human population.

\section{Summary and conclusions}

Developmental exposure to TCDD has been fairly consistently linked with decreased cauda epididymal and ejaculatory sperm counts in animal studies, although at higher dose lev-els than those used by Mably et al. (1992a). Indeed, strengths of the animal literature are the demonstration of adverse effects on cauda epididymal sperm counts in multiple rodent species. The main weaknesses include different methods used to quantify sperm count; the paucity of studies that have examined TCDD effects on DSP and the ambiguous nature of those results; the absence of documented changes in testicular and spermatozoa morphology; and the divergence of effects of TCDD upon sperm counts and circulating androgen levels. Therefore, we find no credible evidence to support the conclusion that TCDD adversely affects spermatogenesis, with the exception of a small number of male rats in which testicular and epididymal lesions have been described (Ohsako et al. 2001). Alternatively, we suggest that effects of TCDD on androgen signaling, reproductive organ weights, and sperm transit through the epididymides are more plausible potential explanations for the reported decrease in epididymal sperm counts. 


\section{References}

Adler ID. 1996. Comparison of the duration of spermatogenesis between male rodents and humans. Mutat Res 352:169-172.

Anderson DR, Fisher R. 2002. Sources of dioxins in the United Kingdom: the steel industry and other sources. Chemosphere 46:371-381.

Aragon AC, Kopf PG, Campen MJ, Huwe JK, Walker MK. 2008. In utero and lactational 2,3,7,8-tetrachlorodibenzo-p-dioxin exposure: effects on fetal and adult cardiac gene expression and adult cardiac and renal morphology. Toxicol Sci 101:321-330.

Atanassova NN, Walker M, McKinnell C, Fisher JS, Sharpe RM. 2005. Evidence that androgens and oestrogens, as well as follicle-stimulating hormone, can alter Sertoli cell number in the neonatal rat. J Endocrinol 184:107-117.

Auger J, Kunstmann JM, Czyglik F, Jouannet P. 1995. Decline in semen quality among fertile men in Paris during the past 20 years. N Engl J Med 332:281285.

Aylward LL, Lamb JC, Lewis SC. 2005. Issues in risk assessment for developmental effects of 2,3,7,8-tetrachlorodibenzo-p-dioxin and related compounds. Toxicol Sci 87:3-10.

Baccarelli A, Pesatori AC, Consonni D, Mocarelli P, PattersonDGJr, Caporaso NE, et al. 2005a. Health status and plasma dioxin levels in chloracne cases 20 years after the Seveso, Italy accident. Br J Dermatol 152:459-465.

Baccarelli A, Pfeiffer R, Consonni D, Pesatori AC, Bonzini M, PattersonDGJr, et al. 2005b. Handling of dioxin measure-ment data in the presence of non-detectable values: overview of available methods and their application in the Seveso chloracne study. Chemosphere 60:898-906.

Barlow N, Foster PMD. 2003. Pathogenesis of male reproductive tract lesions from gestation through adulthood following in utero exposure to $\operatorname{di}(n$-butyl) phthalate. Toxicol Pathol 31:397-410.

Bell DR, Clode S, Fan MQ, Fernandes A, Foster PM, Jiang T, et al. 2007a. Toxicity of 2,3,7,8-tetrachlorodibenzo-p-dioxin in the developing male Wistar(Han) rat. I: No decrease in epididymal sperm count after a single acute dose. Toxicol Sci 99:214-223.

Bell DR, Clode S, Fan MQ, Fernandes A, Foster PM, Jiang T, et al. 2007b. Toxicity of 2,3,7,8-tetrachlorodibenzo-p-dioxin in the developing male Wistar(Han) rat. II: chronic dosing causes developmental delay. Toxicol Sci 99:224-233.

Bell DR, Clode S, Fan MQ, Fernandes A, Foster PM, JiangT, et al. 2007c. Relationships between tissue levels of 2,3,7,8-tetrachlorodibenzo-p-dioxin (TCDD), mRNAs, and toxicity in the developing male Wistar(Han) rat. Toxicol Sci 99:591-604.

Birnbaum LS. 1994. Endocrine effects of prenatal exposure to PCBs, doxins, and other xenobiotics: implications for policy and future research. Environ Health Perspect 102:676-679.
Birnbaum LS, Harris MW, Stocking LM, Clark AM, Morrissey RE. 1989. Retinoic acid and 2,3,7,8-tetrachlorodibenzo- $p$-dioxin selectively enhance teratogenesis in C57BL/6N mice. Toxicol Appl Pharmacol 98:487-500.

Bjerke DL, Brown TJ, MacLusky NJ, Hochberg RB, PetersonRE. 1994. Partial demasculinization and feminization of sex behavior in male rats by inutero and lactational exposure to 2,3,7,8-tetrachlorodibenzo-p-dioxin is not associated with alterations in estrogen receptor binding or volumes of sexually differentiated brain nuclei. Toxicol Appl Pharmacol 127:258-267.

Bjerke DL, Peterson RE. 1994. Reproductive toxicity of 2,3,7,8-tetrachlorodibenzo-p-dioxin in male rats: different effects of inutero versus lactational exposure. Toxicol Appl Pharmacol 127:241-249.

Carlsen E, Giwercman A, Keiding N, Skakkebaek NE. 1992. Evidence for decreasing quality of semen during past 50 years. BMJ 305:609-613.

Chahoud I, Hartmann J, Rune GM, Neubert D. 1992. Reproductive toxicity and toxicokinetics of 2,3,7,8tetrachlorodibenzo-p-dioxin. 3. Effects of single doses on the testis of male rats. Arch Toxicol 66:567572.

Chahoud I, Krowke R, Schimmel A, Merker HJ, Neubert D. 1989. Reproductive toxicity and pharmacokinetics of 2,3,7,8-tetrachlorodibenzo-p-dioxin. 1. Effects of high doses on the fertil-ity of male rats. Arch Toxicol 63:432-439.

Comhaire FH, Mahmoud AM, Schoonjans F. 2007. Sperm qual-ity, birth rates and the environment in Flanders (Belgium). Reprod Toxicol 23:133-137.

Cooper TG, Teung C-H, Jones R, Orgebin-Crist M-C, Robaire B. 2002. Rebuttal of a role for the epididymis in sperm quality control by phagocytosis of defective sperm. J Cell Sci 115:5-7.

Cyr DG, Gregory M, Dufresnes J, Dube E, Chan PTK, Hermo L. 2007. The orchestration of occludin, claudins, catenins and cadherins as players involved in maintenance of the blood-epididymal barrier in animals and humans. Asian J Androl 9:463-475.

De Celis R, Feria-Velasco A, Gonzalez-Unzaga M, Torres-Calleja J, Pedron-Nuevo N. 2000. Semen quality of workers occupationally exposed to hydrocarbons. Fertil Steril 73:221-228.

De Gendt K, Swinnen JV, Saunders PT, Schoonjans L, DewerchinM, Devos A, et al. 2004. A Sertoli cellselective knockout of the androgen receptor causes spermatogenic arrest in meiosis. Proc Natl Acad Sci USA 101:1327-1332.

Denison MS, Nagy SR. 2003. Activation of the aryl hydrocarbon receptor by structurally diverse exogenous and endogenous chemicals. Annu Rev Pharmacol Toxicol 43:309-334.

Dhooge W, van Larebeke N, Koppen G, Nelen V, Schoeters G, VlietinckR, et al. 2006. Serum dioxin-like activity is associated with reproductive parameters in young men from the general Flemish population. Environ Health Perspect 114:1670-1676. 
Dimich-Ward H, Hertzman C, Teschke K, Hershler R, Marion SA, Ostry A, et al. 1996. Reproductive effects of paternal exposure to chlorophenate wood preservatives in the sawmill industry. Scand J Work Environ Health 22:267-273.

Dolwick KM, Schmidt JV, Carver LA, Swanson HI, BradfieldCA. 1993. Cloning and expression of a human Ah receptor cDNA. Mol Pharmacol 44:911-917.

Eskenazi B, Mocarelli P, Warner M, Samuels S, Vercellini P, OliveD, et al. 2000. Seveso Women's Health Study: a study of the effects of 2,3,7,8-tetrachlorodibenzo-p-dioxin on reproductive health. Chemosphere 40:1247-1253.

Eskenazi B, Wyrobek A, Fenster L, Katz D, Sadler M, Lee J, et al. 1991. A study of the effect of perchloroethylene exposure on semen quality in dry cleaning workers. Am J Ind Med 20:575-591.

Fan F, Rozman KK. 1995. Short- and long-term biochemical effects of 2,3,7,8-tetrachlorodibenzo- $p$ dioxin in female Long-Evans rats. Toxicol Lett 75:209-216.

Faqi AS, Chahoud I. 1998. Antiestrogenic effects of low doses of 2,3,7,8-TCDD in offspring of female rats exposed through-out pregnancy and lactation. Bull Environ Contam Toxicol 61:462-469.

Faqi AS, Dalsenter PR, Merker HJ, Chahoud I. 1998. Reproductive toxicity and tissue concentrations of low doses of 2,3,7,8-tetrachlorodibenzo-p-dioxin in male offspring rats exposed throughout pregnancy and lactation. Toxicol Appl Pharmacol 150:383-392.

Fisher MT, Nagarkatti M, Nagarkatti PS. 2005. Aryl hydrocarbon receptor-dependent induction of loss of mitochondrial membrane potential in epididydimal spermatozoa by 2,3,7,8-tetrachlorodibenzo- $p$ dioxin (TCDD). Toxicol Lett 157:99-107.

Flaws JA, Sommer RJ, Silbergeld EK, Peterson RE, HirshfieldAN. 1997. Inutero and lactational exposure to 2,3,7,8-tetrachlorodibenzo-p-dioxin (TCDD) induces genital dysmorphogenesis in the female rat. Toxicol Appl Pharmacol 147:351-362.

Foster WG, Holloway AC, Hughes CL Jr. 2005. Dioxinlike activity and maternal thyroid hormone levels in second trimester maternal serum. Am J Obstet Gynecol 193:1900-1907.

Grassman JA, Masten SA, Walker NJ, Lucier GW. 1998. Animal models of human response to dioxins. Environ Health Perspect 106(suppl 2):761-775.

Gray LE Jr, Kelce WR, Monosson E, Ostby JS, Birnbaum LS. 1995. Exposure to TCDD during development permanently alters reproductive function in male Long Evans rats and hamsters: reduced ejaculated and epididymal sperm numbers and sex accessory gland weights in offspring with normal androgenic status. Toxicol Appl Pharmacol 131:108-118.

Gray LE Jr, Ostby JS. 1995. Inutero 2,3,7,8-tetrachlorodiben-zo-p-dioxin (TCDD) alters reproductive morphology and function in female rat offspring. Toxicol Appl Pharmacol 133:285-294.

Gray LE, Ostby JS, Kelce WR. 1997a. A dose-response analysis of the reproductive effects of a single gestational dose of 2,3,7,8-tetrachlorodibenzo- $p$-dioxin in male Long Evans Hooded rat offspring. Toxicol Appl Pharmacol 146:11-20.
Gray LE, Wolf C, Mann P, Ostby JS. 1997b. Inutero exposure to low doses of 2,3,7,8-tetrachlorodibenzo- $p$-dioxin alters reproductive development of female Long Evans hooded rat offspring. Toxicol Appl Pharmacol 146:237-244.

Guo YL, Hsu PC, Hsu CC, Lambert GH. 2000. Semen quality after prenatal exposure to polychlorinated biphenyls and dibenzofurans. Lancet 356: 12401241.

Halldorsson TI, Thorsdottir I, Meltzer HM, Strom M, Olsen SF. 2009. Dioxin-like activity in plasma among Danish pregnant women: dietary predictors, birth weight and infant development. Environ Res 109:2228.

Harper PA, Prokipcak RD, Bush LE, Golas CL, Okey AB. 1991. Detection and characterization of the Ah receptor for 2,3,7,8-tetrachlorodibenzo-p-dioxin in the human colon adenocarcinoma cell line LS180. Arch Biochem Biophys 290:27-36.

Heilier JF, Donnez J, Nackers F, Rousseau R, Verougstraete V, RosenkranzK, et al. 2007. Environmental and host-associated risk factors in endometriosis and deep endometriotic nodules: a matched case-control study. Environ Res 103:121-129.

Heimler I, Trewin AL, Chaffin CL, Rawlins RG, Hutz RJ. 1998. Modulation of ovarian follicle maturation and effects on apoptotic cell death in Holtzman rats exposed to 2,3,7,8-tetrachlorodibenzo-pdioxin (TCDD) inutero and lactationally. Reprod Toxicol 12:69-73.

Henry EC, Gasiewicz TA. 1987. Changes in thyroid hormones and thyroxine glucuronidation in hamsters compared with rats following treatment with $2,3,7,8$ tetrachlorodibenzo- $p$-dioxin. Toxicol Appl Pharmacol 89:165-174.

Hess RA. 2002. The efferent ductules: structure and functions. In: The Epididymis: From Molecules to Clinical Practice (Robaire B, Hinton, BT eds). New York:Plenum, 49-80.

Hess RA, Schaeffer DJ, Eroschenko VP, Keen JE. 1990. Frequency of the stages in the cycle of the seminiferous epithelium in the rat. Biol Reprod 43:517524.

Hewitt LM, Parrott JL, McMaster ME. 2006. A decade of research on the environmental impacts of pulp and paper mill effluents in Canada: sources and characteristics of bioactive substances. J Toxicol Environ Health B Crit Rev 9:341-356.

Hogaboam JP, Moore AJ, Lawrence BP. 2008. The aryl hydro-carbon receptor affects distinct tissue compartments during ontogeny of the immune system. Toxicol Sci 102:160-170.

Hoogenboom LA, Van Eijkeren JC, Zeilmaker MJ, MengelersMJ, Herbes R, Immerzeel J, et al. 2007. A novel source for dioxins present in recycled fat from gelatin production. Chemosphere 68:814-823.

Irvine S, Cawood E, Richardson D, MacDonald E, Aitken J. 1996. Evidence of deteriorating semen quality in the United Kingdom: birth cohort study in 577 men in Scotland over 11 years. BMJ 312:467-471.

Ishimura R, Kawakami T, Ohsako S, Nohara K, Tohyama C. 2006. Suppressive effect of 2,3,7,8-tetrachlorodibenzo-p-dioxin on vascular remodeling that takes place in the normal labyrinth zone of rat placenta during late gestation. Toxicol Sci 91:265-274. 
Johnson L, Dickerson R, Safe SH, Nyberg CL, Lewis RP, Welsh TH Jr. 1992. Reduced Leydig cell volume and function in adult rats exposed to 2,3,7,8-tetrachlorodibenzo- $p$-dioxin without a significant effect on spermatogenesis. Toxicology 76:103-118.

Johnston H, Baker PJ, Abel M, Charlton HM, Jackson G, FlemingL, et al. 2004. Regulation of Sertoli cell number and activity by follicle-stimulating hormone and androgen during postnatal development in the mouse. Endocrinology 145:318-329.

Joint FAO/WHO (Food and Agriculture Organization/ World Health Organization) Expert Committee on Food Additives. 2009. Fifty-Seventh Meeting, Rome, 5-14 June 2001, Summary and Conclusions. Available: http://www.who.int/ipcs/food/jecfa/summaries/ en/summary_57.pdf [accessed 17 February 2010].

Jorgensen N, Andersen AG, Eustache F, Irvine DS, Suominen J, Petersen JH, et al. 2001. Regional differences in semen quality in Europe. Hum Reprod 16:1012-1019.

Jorgensen N, Asklund C, Carlsen E, Skakkebaek NE. 2006. Coordinated European investigations of semen quality: results from studies of Scandinavian young men is a matter of concern. Int J Androl 29:54-61.

Jorgensen N, Carlsen E, Nermoen I, Punab M, Suominen J, AndersenAG, et al. 2002. East-west gradient in semen quality in the Nordic-Baltic area: a study of men from the general population in Denmark, Norway, Estonia and Finland. Hum Reprod 17:2199_ 2208.

Kawakami T, Ishimura R, Nohara K, Takeda K, Tohyama C, OhsakoS. 2006. Differential susceptibilities of Holtzman and Sprague-Dawley rats to fetal death and placental dysfunction induced by 2,3,7,8-teterachlorodibenzo- $p$-dioxin (TCDD) despite the identical primary structure of the aryl hydrocarbon receptor. Toxicol Appl Pharmacol 212:224-236.

Kohn MC. 2000. Effects of TCDD on thyroid hormone homeostasis in the rat. Drug Chem Toxicol 23:259277.

Kollara A, Brown TJ. 2006. Functional interaction of nuclear receptor coactivator 4 with aryl hydrocarbon receptor. Biochem Biophys Res Commun 346:526-534.

Koopman-Esseboom C, Morse DC, Weisglas-Kuperus N, Lutkeschipholt IJ, Van der Paauw CG, Tuinstra LG, et al. 1994. Effects of dioxins and polychlorinated biphenyls on thyroid hormone status of pregnant women and their infants. Pediatr Res 36:468473.

Koopman-Esseboom C, Weisglas-Kuperus N, de Ridder MA, Van der Paauw CG, Tuinstra LG, Sauer PJ. 1996. Effects of polychlorinated biphenyl/dioxin exposure and feeding type on infants' mental and psychomotor development. Pediatrics 97:700-706.

Larsen JC. 2006. Risk assessments of polychlorinated dibenzo-p-dioxins, polychlorinated dibenzofurans, and dioxin-like polychlorinated biphenyls in food. Mol Nutr Food Res 50:885-896.

Leijs MM, Koppe JG, Olie K, van Aalderen WM, Voogt P, VulsmaT, et al. 2008. Delayed initiation of breast development in girls with higher prenatal dioxin exposure; a longitudinal cohort study. Chemosphere 73:999-1004.
Li W, Harper PA, Tang BK, Okey AB. 1998. Regulation of cyto-chrome P450 enzymes by aryl hydrocarbon receptor in human cells: CYP1A2 expression in the LS180 colon carcinoma cell line after treatment with 2,3,7,8-tetrachlorodibenzo-p-dioxin or 3-methylcholanthrene. Biochem Pharmacol 56:599-612.

Lin LF, Lee WJ, Chang-Chien GP. 2006. Emissions of polychlorinated dibenzo- $p$-dioxins and dibenzofurans from various industrial sources. J Air Waste Manag Assoc 56:1707-1715.

Loeffler IK, Peterson RE. 1999. Interactive effects of TCDD and $p, p^{\prime}-\mathrm{DDE}$ on male reproductive tract development in inutero and lactationally exposed rats. Toxicol Appl Pharmacol 154:28-39.

Longnecker MP, Michalek JE. 2000. Serum dioxin level in rela-tion to diabetes mellitus among Air Force veterans with background levels of exposure. Epidemiology 11:44-48.

Mably TA, Bjerke DL, Moore RW, Gendron-Fitzpatrick A, PetersonRE. 1992a. Inutero and lactational exposure of male rats to 2,3,7,8-tetrachlorodibenzop-dioxin. 3. Effects on spermatogenesis and reproductive capability. Toxicol Appl Pharmacol 114:118126.

Mably TA, Moore RW, Goy RW, Peterson RE. 1992b. Inutero and lactational exposure of male rats to 2,3,7,8-tetrachlo-rodibenzo-p-dioxin. 2. Effects on sexual behavior and the regulation of luteinizing hormone secretion in adulthood. Toxicol Appl Pharmacol 114:108-117.

Mably TA, Moore RW, Peterson RE. 1992c. In utero and lacta-tional exposure of male rats to $2,3,7,8$ tetrachlorodibenzo- $p$-dioxin. Effects on androgenic status. Toxicol Appl Pharmacol 114:97-107.

McKinnell C, Atanassova N, Williams K, Fisher JS, WalkerM, Turner KJ, et al. 2000. Suppression of androgen action and the induction of gross abnormalities of the reproductive tract in male rats treated neonatally with diethylstil-besterol. J Androl 22:323-338.

Michalek JE, Pirkle JL, Caudill SP, Tripathi RC, Patterson DG Jr, Needham LL. 1996. Pharmacokinetics of TCDD in veterans of Operation Ranch Hand: 10year follow-up. J Toxicol Environ Health 47:209220.

Michalek JE, Pirkle JL, Needham LL, Patterson DG Jr, Caudill SP, Tripathi RC, et al. 2002. Pharmacokinetics of 2,3,7,8-tetra-chlorodibenzo-p-dioxin in Seveso adults and veterans of operation Ranch Hand. J Expo Anal Environ Epidemiol 12:44-53.

Michalek JE, Tripathi RC, Caudill SP, Pirkle JL. 1992. Investigation of TCDD half-life heterogeneity in veterans of Operation Ranch Hand. J Toxicol Environ Health 35:29-38.

Mocarelli P, Brambilla P, Gerthoux PM, Patterson DG Jr, Needham LL. 1996. Change in sex ratio with exposure to dioxin [Letter]. Lancet 348:409.

Mocarelli P, Gerthoux PM, Ferrari E, Patterson DG Jr, KieszakSM, Brambilla P, et al. 2000. Paternal concentrations of dioxin and sex ratio of offspring. Lancet 355:1858-1863.

Mocarelli P, Gerthoux PM, Patterson DG Jr, Milani S, LimontaG, Bertona M, et al. 2008. Dioxin exposure, from infancy through puberty, produces endocrine disruption and affects human semen quality. Environ Health Perspect 116:70-77. 
Moore RW, Potter CL, Theobald HM, Robinson JA, PetersonRE. 1985. Androgenic deficiency in male rats treated with 2,3,7,8-tetrachlorodibenzo-p-dioxin. Toxicol Appl Pharmacol 79:99-111.

Morrow D, Qin C, Smith R, Safe S. 2004. Aryl hydrocarbon receptor inhibition of LNCaP prostate cancer cell growth and hormone-induced transactivation. J Steroid Biochem Mol Biol 88:27-36.

National Center for Biotechnology Information. 2009. PubMed. Available: http://www.ncbi.nlm. nih.gov/ pubmed/ [accessed 15 December 2008].

Ohsako S, Miyabara Y, Nishimura N, Kurosawa S, Sakaue M, IshimuraR, et al. 2001. Maternal exposure to a low dose of 2,3,7,8-tetrachlorodibenzo-p-dioxin (TCDD) suppressed the

development of reproductive organs of male rats: dosedependent increase of mRNA levels of 5alpha-reductase type 2 in contrast to decrease of androgen receptor in the pubertal ventral prostate. Toxicol Sci 60:132-143.

Ohsako S, Miyabara Y, Sakaue M, Ishimura R, Kakeyama M, IzumiH, et al. 2002. Developmental stagespecific effects of perinatal 2,3,7,8-tetrachlorodibenzo-p-dioxin exposure on reproductive organs of male rat offspring. Toxicol Sci 66:283-292.

Pal PC, Rajalakshmi M, Manocha M, Sharma RS, Mittal S, Rao DN. 2006. Semen quality and sperm functional parameters in fertile Indian men. Andrologia 38:20-25.

Pang AL, Johnson W, Ravindranath N, Dym M, Rennert OM, ChanWY. 2006. Expression profiling of purified male germ cells: stage-specific expression patterns related to meiosis and postmeiotic development. Physiol Genomics 24:75-85.

Pavuk M, Schecter AJ, Akhtar FZ, Michalek JE. 2003. Serum 2,3,7,8-tetrachlorodibenzo-p-dioxin (TCDD) levels and thyroid function in Air Force veterans of the Vietnam War. Ann Epidemiol 13:335-343.

Phillips KP, Tanphaichitr N. 2008. Human exposure to endo-crine disrupters and semen quality. J Toxicol Environ Health B Crit Rev 11:188-220.

Robaire B, Hinton B, Orgebin-Crist MC. 2006. The epididymis. In: Physiology of Reproduction (Knobil E, Neill J, eds). 3rd ed. New York: Elsevier, 10711148.

Robb GW, Amann RP, Killian GJ. 1978. Daily sperm production and epididymal sperm reserves of pubertal and adult rats. J Reprod Fertil 54:103-107.

Robles R, Morita Y, Mann KK, Perez GI, Yang S, Matikainen T, et al. 2000. The aryl hydrocarbon receptor, a basic helix-loop-helix transcription factor of the PAS gene family, is required for normal ovarian germ cell dynamics in the mouse. Endocrinology 141:450-453.

Roman BL, Pollenz RS, Peterson RE. 1998. Responsiveness of the adult male rat reproductive tract to $2,3,7,8$ tetrachlorodibenzo-p-dioxin exposure: Ah receptor and ARNT expression, CYP1Al induction, and Ah receptor down-regulation. Toxicol Appl Pharmacol 150:228-239.
Roman BL, Sommer RJ, Shinomiya K, Peterson RE. 1995. In utero and lactational exposure of the male rat to 2,3,7,8-tetrachlorodibenzo-p-dioxin: impaired prostate growth and development without inhibited androgen production. Toxicol Appl Pharmacol 134:241-250.

Rose JQ, Ramsey JC, Wentzler TH, Hummel RA, Gehring PJ. 1976. The fate of 2,3,7,8-tetrachlorodibenzo-p-dioxin following single and repeated oral doses to the rat. Toxicol Appl Pharmacol 36:209-226.

Ruz R, Gregory M, Smith CE, Cyr DG, Hess RA, Lubahn DB, et al. 2006. Expression of aquaporins in the efferent ducts, sperm counts, and sperm motility in estrogen receptor-alpha deficient mice fed lab chow versus casein. Mol Reprod Dev 73:226-237.

Safe S, Wang F, Porter W, Duan R, McDougal A. 1998. Ah receptor agonist as endocrine disruptors: antiestrogenic activity and mechanisms. Toxicol Lett 102-103:343-347.

Schecter A, Birnbaum L, Ryan JJ, Constable JD. 2006. Dioxins: an overview. Environ Res 101:419-428.

Schecter A, Cramer P, Boggess K, Stanley J, Olson JR. 1997. Levels of dioxins, dibenzofurans, PCB and DDE congeners in pooled food samples collected in 1995 at supermarkets across the United States. Chemosphere 34:1437-1447.

Schecter A, Cramer P, Boggess K, Stanley J, Papke O, Olson J, et al. 2001. Intake of dioxins and related compounds from food in the U.S. population. J Toxicol Environ Health A 63:1-18.

Schecter A, Dellarco M, Papke O, Olson J. 1998a. A comparison of dioxins, dibenzofurans and coplanar PCBs in uncooked and broiled ground beef, catfish and bacon. Chemosphere 37:1723-1730.

Schecter A, Li L. 1997. Dioxins, dibenzofurans, dioxinlike PCBs, and DDE in U.S. fast food, 1995. Chemosphere 34:1449-1457.

Schecter A, Ryan JJ, Papke O. 1998b. Decrease in levels and body burden of dioxins, dibenzofurans, PCBS, DDE, and HCB in blood and milk in a mother nursing twins over a thirty-eight month period. Chemosphere 37:1807-1816.

Schultz R, Suominen J, Varre T, Hakovirta H, Parvinen M, ToppariJ, et al. 2003. Expression of aryl hydrocarbon receptor and aryl hydrocarbon receptor nuclear translocator messenger ribonucleic acids and proteins in rat and human testis. Endocrinology 144:767-776.

Sharpe RM. 2009. Male Reproductive Health Disorders and the Potential Role of Exposure to Environmental Chemicals. London:CHEM Trust. Available: http://www.chemtrust.org.uk/documents/ProfRS H A R P E - M a l e R e p rod uctive H e alt hCHEMTrust09.pdf [accessed 17February 2010].

Sharpe RM, McKinnell C, Kivlin C, Fisher JS. 2003. Proliferation and functional maturation of Sertoli cells, and their relevance to disorders of testis function in adulthood. Reproduction 125:769-784.

Siiteri PK, Wilson JD. 1974. Testosterone formation and metabolism during male sexual differentiation in the human embryo. J Clin Endocrinol Metab 38:113-125. 
Simanainen U, Adamsson A, Tuomisto JT, Miettinen HM, ToppariJ, Tuomisto J, et al. 2004a. Adult 2,3,7,8-tetrachloro-dibenzo- $p$-dioxin (TCDD) exposure and effects on male reproductive organs in three differentially TCDD-susceptible rat lines. Toxicol Sci 81:401-407.

Simanainen U, Haavisto T, Tuomisto JT, Paranko J, Toppari J, Tuomisto J, et al. 2004b. Pattern of male reproductive sys-tem effects after inutero and lactational 2,3,7,8-tetrachloro-dibenzo-p-dioxin (TCDD) exposure in three differentially TCDD-sensitive rat lines 2. Toxicol Sci 80:101-108.

Sommer RJ, Ippolito DL, Peterson RE. 1996. Inutero and lactational exposure of the male Holtzman rat to 2,3,7,8-tetrachlorodibenzo-p-dioxin: decreased epididymal and ejaculated sperm numbers without alterations in sperm transit rate. Toxicol Appl Pharmacol 140:146-153.

Sutovsky P, Moreno R, Ramalho-Santos J, Dominiko T, Thompson WE, Schatten G. 2001. A putative, ubiquitin-dependent mechanism for the recognition and elimination of defective spermatozoa in the mammalian epididymis. J Cell Sci 114:1665-1675.

Tan KA, De Gendt K, Atanassova N, Walker M, Sharpe RM, Saunders PT, et al. 2005a. The role of androgens in Sertoli cell proliferation and functional maturation: studies in mice with total or Sertoli cell-selective ablation of the androgen receptor. Endocrinology 146:2674-2683.

Tan KA, Turner KJ, Saunders PT, Verhoeven G, De Gendt K, Atanassova N, et al. 2005b. Androgen regulation of stage-dependent cyclin D2 expression in Sertoli cells suggests a role in modulating androgen action on spermatogenesis. Biol Reprod 72:11511160.

Theobald HM, Peterson RE. 1997. In utero and lactational exposure to 2,3,7,8-tetrachlorodibenzo-rhodioxin: effects on development of the male and female reproductive system of the mouse. Toxicol Appl Pharmacol 145:124-135.

Thornton J, McCally M, Orris P, Weinberg J. 1996. Hospitals and plastics. Dioxin prevention and medical waste incinerators. Public Health Rep 111:298-313.

Toft G, Long M, Kruger T, Hjelmborg PS, Bonde JP, Rignell-Hydbom A, et al. 2007. Semen quality in relation to xeno-hormone and dioxin-like serum activity among Inuits and three European populations. Environ Health Perspect 115(suppl 1):15-20.

Van den Berg M, Birnbaum LS, Denison M, De Vito M, FarlandW, Feeley M, et al. 2006. The 2005 World Health Organization reevaluation of human and mammalian toxic equivalency factors for dioxins and dioxin-like compounds. Toxicol Sci 93:223-241.

Van Waeleghem K, De Clercq N, Vermeulen L, Schoonjans F, ComhaireF. 1996. Deterioration of sperm quality in young healthy Belgian men. Hum Reprod 11:325-329.

Vezina CM, Allgeier SH, Moore RW, Lin TM, Bemis JC, HardinHA, et al. 2008. Dioxin causes ventral prostate agenesis by disrupting dorsoventral patterning in developing mouse prostate. Toxicol Sci 106:488496.
Vreugdenhil HJ, Lanting CI, Mulder PG, Boersma ER, Weisglas-Kuperus N. 2002. Effects of prenatal PCB and dioxin back-ground exposure on cognitive and motor abilities in Dutch children at school age. J Pediatr 140:48-56.

Wang SL, Lin CY, Guo YL, Lin LY, Chou WL, Chang LW. 2004. Infant exposure to polychlorinated dibenzo-p-dioxins, dibenzofurans and biphenyls (PCDD/ Fs, PCBs) - correlation between prenatal and postnatal exposure. Chemosphere 54:1459-1473.

Weisglas-Kuperus N, Patandin S, Berbers GAM, Sas TCJ, Mulder PGH, Sauer PJJ, et al. 2000. Immunologic effects of background exposure to polychlorinated biphenyls and dioxins in Dutch preschool children. Environ Health Perspect 108:1203-1207.

Welsh M, Saunders TK, Fisken M, Scott HM, Hutchison GR, Smith LB, et al. 2008. Identification of a programming window for reproductive tract masculinization, disruption of which leads to hypospadias and cryptorchidism. J Clin Invest 118:14791490.

Wilker C, Johnson L, Safe S. 1996. Effects of developmental exposure to indole-3-carbinol or $2,3,7,8$ tetrachlorodibenzo- $p$-dioxin on reproductive potential of male rat offspring. Toxicol Appl Pharmacol 141:68-75.

Wittsiepe J, Furst P, Schrey P, Lemm F, Kraft M, Eberwein G, et al. 2007. PCDD/F and dioxin-like PCB in human blood and milk from German mothers. Chemosphere 67:S286-S294.

Wolf CJ, Ostby JS, Gray LE Jr. 1999. Gestational exposure to 2,3,7,8-tetrachlorodibenzo-p-dioxin (TCDD) severely alters reproductive function of female hamster offspring. Toxicol Sci 51:259-264.

Yonemoto J, Ichiki T, Takei T, Tohyama C. 2005. Maternal exposure to 2,3,7,8-tetrachlorodibenzo- $p$-dioxin and the body burden in offspring of LongEvans rats. Environ Health Prev Med 10:21-32.

Younglai EV, Collins JA, Foster WG. 1998. Canadian semen quality: an analysis of sperm density among eleven academic fertility centers. Fertil Steril 70:7680.

Zhou Q, Clarke L, Nie R, Carnes K, Lai LW, Lien YH, et al. 2001. Estrogen action and male fertility: roles of the sodium/hydrogen exchanger-3 and fluid reabsorption in reproduction tract function. Proc Natl Acad Sci USA 98:14132-14137.

Received 15 June 2009

Accepted 17 December 2009 